and phyllite, but are also found in chlorite schists and ultramafic rocks (on Anap nunâ). They generally have carbonate (ankerite and calcite), chlorite and quartz in the matrix. The breccia is often slightly porous. The sulphides, generally located in the matrix, consist dominantly of large, anhedral chalcopyrite with minor amounts of euhedral pyrite.

In the Eqe area several chalcopyrite-pyrite bearing breccia zones have been found (fig. 5), and in the southern part of the area a breccia up to $5 \mathrm{~m}$ wide could be followed $100 \mathrm{~m}$ along strike. The samples GGU 341442 , $341445,341448,341453$ and 341489 (Table 2) were collected in this zone. This breccia is located where Steenfelt (1987) found elevated gold values (up to $43 \mathrm{ppb}$ ) in stream sediments.

In the supracrustals at Arveprinsen Ejland a 1 to $5 \mathrm{~m}$ wide breccia zone has been followed for about $5 \mathrm{~km}$. The breccia ( 3 on fig. 1 ) is locally rich in sulphides, mainly pyrite, but locally massive chalcopyrite and sphalerite occur.

Acknowledgements. The field work was partly financed by grants from the Danish Natural Science Research Council (j.nr. 81-5656 (B. H.) and j.nr. 81-5650 (L. S.)). B. Damgaard carried out the atomic absorption determinations.

\section{References}

Escher, A. \& Burri, M. 1967: Stratigraphy and structural development of the Precambrian rocks in the area north-east of Disko Bugt, West Greenland. Rapp. Grønlands geol. Unders. 13, 28 pp.

Escher, A. \& Pulvertaft. T. C. R. 1976: Rinkian mobile belt of West Greenland. In Escher, A. \& Watt, W. S. (edit.) Geology of Greenland, 104-119. Copenhagen: Geol. Surv. Greenland.

Hoffmann, P. F in press: United plates of America, the birth of a craton: Annl Rev. Earth Planet. Sci. 16.

Kalsbeek, F., Taylor, P. N. \& Pidgeon, R. T. in press: Unreworked Archaean basement and Proterozoic supracrustal rocks from northeastern Disko Bugt, West Greenland: implications for the nature of Proterozoic mobile belts in Greenland. Can. J. Earth. Sci.

Pulvertaft, T. C. R. 1986: The development of thin thrust sheets and basement - cover sandwiches in the southern part of the Rinkian belt, Umanak district, West Greenland. Rapp. Grønlands geol. Unders. 128, 75-87.

Steenfelt, A. 1987: Gold in the fine fraction of stream sediments from supracrustal sequences in West Greenland. Unpubl. intern. GGU rep., 10 pp.

B. H. \& L. S., Institut for Almen Geologi, $\emptyset$ ster Voldgade 10, $D K-1350$ Copenhagen $K$, Denmark.

\title{
Progress in geochemical mapping of West Greenland
}

\author{
Agnete Steenfelt
}

Geochemical mapping based on low density sampling and analysis of stream sediment and stream water is part of the mineral resources evaluation programme undertaken by the Geological Survey of Greenland (Steenfelt $1987 \mathrm{a}, \mathrm{b})$.

In the field season of 1986 two areas were sampled, the inner Disko Bugt region (1:250 000 map sheet 69 V.2 and part of $70 \mathrm{~V} .2$ ), and the Godthåb region (map sheets 64 V.1 and 64 V.2).

\section{Sampling and analysis}

The sampling was carried out by one field team supported by a Bell 206 helicopter from Greenlandair Charter. At each sample station $200-300 \mathrm{~g}$ of stream sediment was collected from four to five sites in the stream bed; a $100 \mathrm{ml}$ stream water sample was taken; and the gamma radiation was measured by averaging five to ten scintillometer readings in the immediate surroundings of the sample site. The sample density is one sample per $20-30 \mathrm{~km}^{2}$.

The 608 stream-sediment samples were dry-sieved in the laboratory and the $<0.1 \mathrm{~mm}$ fraction was analysed by X-ray fluorescence at the Geological Survey of Greenland. A selection of 96 samples were also analysed by Instrumental Neutron Activation at BondarClegg, Canada. The conductivity and the fluoride concentration of the stream water samples were measured in a field laboratory. Table 1 lists the elements and basic statistical parameters for the concentrations determined by X-ray fluorescence and for the water analyses.

The X-ray fluorescence analyses for major and trace elements were made on a Philips PW 1606 multi-channel spectrometer. The analyses were made on glass discs and major elements were determined following the principles of Petersen \& Sørensen (1980) while the pro- 
Table 1. Statistical parameters for the chemical analyses of the $<0.1 \mathrm{~mm}$ fraction of stream-sediment samples from West Greenland

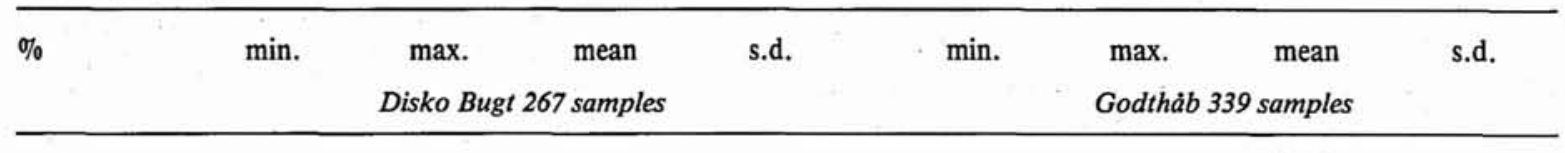

$<0.1 \mathrm{~mm}$ fraction of stream sediment

$\begin{array}{lrrrrrrrr}\mathrm{SiO}_{2} & 38.23 & 73.89 & 64.57 & 5.30 & 38.61 & 80.85 & 62.19 & 4.88 \\ \mathrm{TiO}_{2} & 0.22 & 9.68 & 0.52 & 0.59 & 0.17 & 2.69 & 0.52 & 0.21 \\ \mathrm{Al}_{2} \mathrm{O}_{3} & 8.89 & 24.59 & 13.63 & 1.23 & 7.82 & 17.67 & 13.94 & 0.99 \\ \mathrm{Fe}_{2} \mathrm{O}_{3} & 0.70 & 24.86 & 4.17 & 2.09 & 0.75 & 14.79 & 4.88 & 1.77 \\ \mathrm{MnO} & 0.04 & 0.57 & 0.08 & 0.05 & 0.05 & 0.29 & 0.10 & 0.03 \\ \mathrm{MgO} & 0.47 & 8.06 & 1.62 & 0.97 & 0.99 & 25.46 & 2.52 & 1.80 \\ \mathrm{CaO} & 1.72 & 10.10 & 3.03 & 0.71 & 2.45 & 9.31 & 4.36 & 0.78 \\ \mathrm{~K}_{2} \mathrm{O} & 0.36 & 2.96 & 2.00 & 0.41 & 0.34 & 3.01 & 1.53 & 0.39 \\ \mathrm{P}_{2} \mathrm{O}_{3} & 0.07 & 2.57 & 0.19 & 0.16 & 0.06 & 0.48 & 0.18 & 0.07\end{array}$

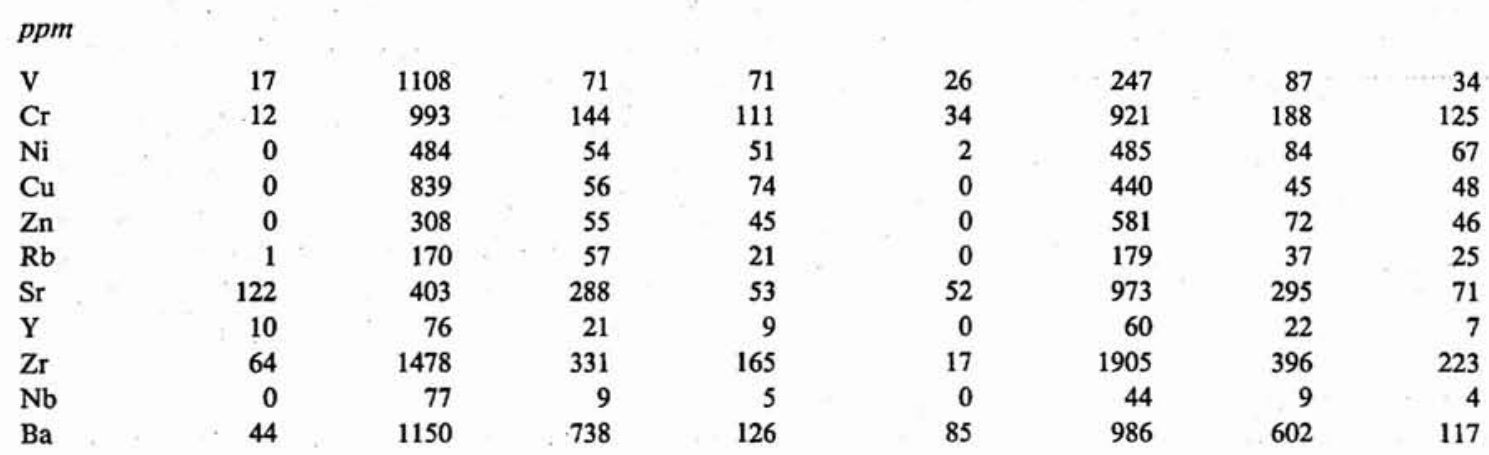

Stream water samples

$p p b$

\begin{tabular}{llllllllll}
$\mathrm{F}$ & 10 & 160 & 16 & 17.8 & 10 & 37 & 11 & 3.77 \\
$\begin{array}{l}\mu \text { ohm }^{-1} \\
\text { Conductivity }\end{array}$ & 7.8 & 260.0 & 28.4 & 27.7 & 6.0 & 92.0 & 20.6 & 11.36 \\
\hline
\end{tabular}

$\mathrm{X}$-ray fluorescence analyses by the Geological Survey of Greenland.

min.: minimum value; max.: maximum value; s.d.: standard deviation.

cedure for trace element determinations is under development by Ib Sørensen. The trace element data used here have been corrected for background but not for effects of matrix and line coincidence, and they must be considered preliminary. However, there are no problems with line coincidence for $\mathrm{Rb}$ and $\mathrm{Cu}$ used in this presentation, and matrix effects are relatively small because of the use of glass discs.

\section{Presentation and preliminary evaluation of results}

As a first approach in the evaluation the two regions are looked upon as two (arbitrarily chosen) segments of the Archaean crust. The Godthåb region is established as Archaean (Bridgwater et al., 1976), and the Disko
Bugt region is described as Archaean with the exception of some supracrustal sequences of probable Proterozoic age (Kalsbeek, 1986; Kalsbeek et al., in press). The average chemical composition of each segment may be estimated using the values of the stream sediment analyses from Table 1 which lists the range, mean, and standard deviation for the elements with concentrations above the analytical detection limit.

Figure 1 illustrates the chemical composition of the two areas. There appears to be a tendency for the crust at Disko Bugt to be richer in $\mathrm{SiO}_{2}, \mathrm{~K}_{2} \mathrm{O}, \mathrm{Rb}, \mathrm{Cu}$, and $\mathrm{Ba}$, and poorer in $\mathrm{Fe}_{2} \mathrm{O}_{3}, \mathrm{MgO}, \mathrm{V}, \mathrm{Ni}, \mathrm{Cr}, \mathrm{MnO}, \mathrm{Zn}$, and $\mathrm{Zr}$, relative to the crust at the Godthåb region. The latter is dominated by granulite facies gneisses and is regarded as a deep crustal level. It is therefore sug- 

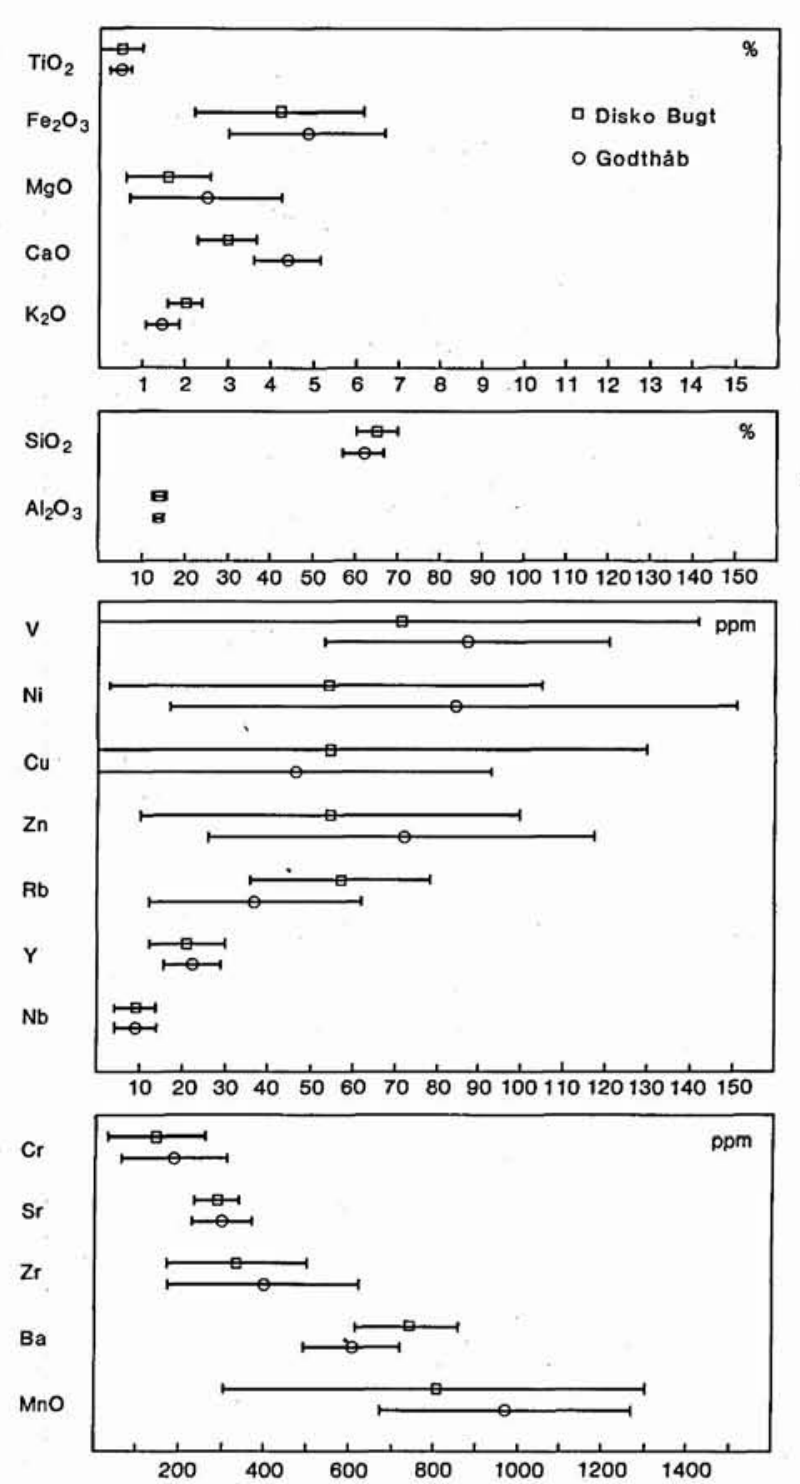

Fig. 1. Graphic presentation of the average chemical composition of the Disko Bugt and Godthăb regions. The bars show the mean standard deviation for the analysis of the $<0.1 \mathrm{~mm}$ fraction of stream-sediment samples.

gested that the Disko Bugt region, being richer in 'felsic' components, represents a higher crustal level.

The distribution of element concentrations within the two regions is illustrated in figs 2 and 3. Symbol maps were made for all elements at the scale of 1:500 000. A geochemical atlas containing all the element maps will be published for each region. In the present preliminary evaluation three elements are chosen to illustrate different distribution patterns. Magnesium and rubidium represent elements associated with basaltic and granitic rocks, respectively, and their distribution patterns reflect major lithogeochemical changes. Copper represents an example of an element associated with the sulphide phase which often appears as an indicator of mineralisation in supracrustal rocks.

Previous studies (Steenfelt \& Kunzendorf, 1979; and unpublished data) have shown that the chemical composition of the fine fraction of stream sediment in Greenland is close to that of the surrounding bedrock. An illustration of this is presented in Table 2 in which seven samples of the Atâ tonalite (Kalsbeek et al., in press) are compared chemically with five sediment samples from streams draining the Atâ tonalite. Considering the fact that the rock samples were not collected with the aim of finding an average composition of the tonalite, the agreement is satisfactory. A differential weathering effect is noted in that feldspar components like $\mathrm{SiO}_{2}$, $\mathrm{Al}_{2} \mathrm{O}_{3}, \mathrm{Na}_{2} \mathrm{O}$, and $\mathrm{Sr}$ have lower values in the sediment, whereas components typically contained in accessory minerals like $\mathrm{P}_{2} \mathrm{O}_{5}, \mathrm{Y}$, and $\mathrm{Zr}$ are enriched in the sediment relative to the rock. In the following, the streamsediment data are treated as representative of the bedrock, and the distribution patterns displayed by the three elements are compared with major geological units and structural features (figs 2 and 3 ).

Table 2. Chemical comparison between rock samples and stream-sediment samples derived from the Atâ tonalite

\begin{tabular}{lrr}
\hline$\%$ & 7 rock samples & 5 stream samples \\
\hline $\mathrm{SiO}_{2}$ & $67.27-72.08$ & $59.83-67.74$ \\
$\mathrm{TiO}_{2}$ & $0.22-0.47$ & $0.35-0.45$ \\
$\mathrm{Al}_{2} \mathrm{O}_{3}$ & $14.74-16.73$ & $12.31-13.63$ \\
$\mathrm{Fe}_{2} \mathrm{O}_{3}$ & $0.25-0.81$ & $3.11-3.67$ \\
$\mathrm{FeO}$ & $1.24-2.30$ & \\
$\mathrm{MnO}$ & $0.03-0.05$ & $0.05-0.16$ \\
$\mathrm{MgO}$ & $0.45-1.06$ & $0.93-1.15$ \\
$\mathrm{CaO}$ & $2.28-3.41$ & $2.47-2.69$ \\
$\mathrm{Na} \mathrm{O}_{2} \mathrm{O}$ & $4.28-5.07$ & $2.95-3.56$ \\
$\mathrm{~K}_{2} \mathrm{O}$ & $1.19-3.23$ & $1.75-2.34$ \\
$\mathrm{P}_{2} \mathrm{O}_{5}$ & $0.08-0.15$ & $0.17-0.30$ \\
& & \\
$p p m$ & & \\
$\mathrm{Rb}$ & $43-99$ & $43-65$ \\
$\mathrm{Sr}$ & $373-471$ & $291-316$ \\
$\mathrm{Y}$ & $5-11$ & $15-32$ \\
$\mathrm{Zr}$ & $91-163$ & $278-381$ \\
$\mathrm{Ba}$ & & $574-751$ \\
$\mathrm{~V}$ & & $50-61$ \\
$\mathrm{Cr}$ & & $85-231$ \\
$\mathrm{Ni}$ & & $23-37$ \\
$\mathrm{Cu}$ & & $0-110$ \\
$\mathrm{Zn}$ & & $23-68$ \\
\hline
\end{tabular}



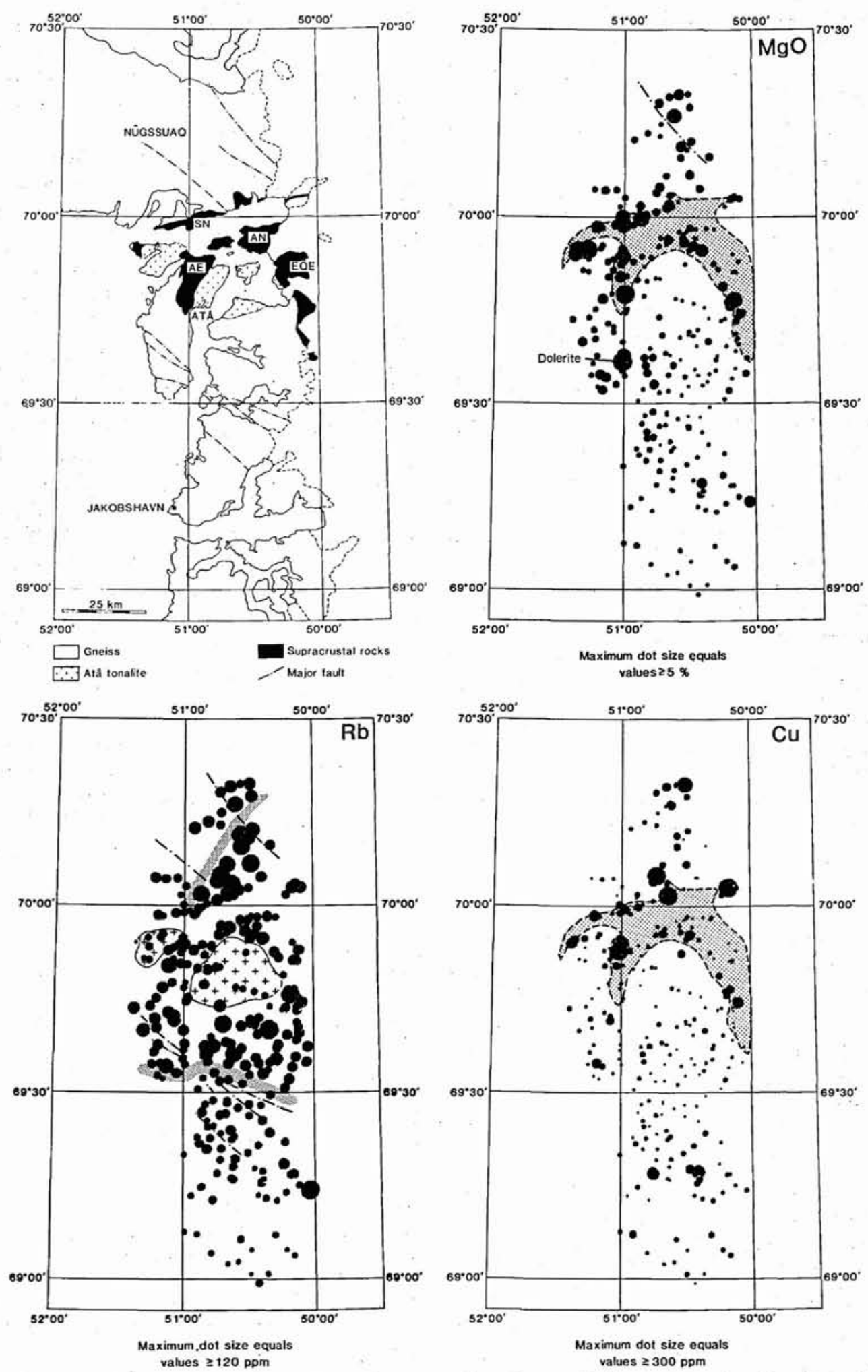

Fig. 2. Simplified geology of the Disko Bugt region and corresponding element distribution maps based on X-ray fluorescence analysis of the $<0.1 \mathrm{~mm}$ fraction of stream sediment. The dot size is linear proportional to the element concentration up to a maximum of $5 \%$ for $\mathrm{MgO}, 120 \mathrm{ppm}$ for $\mathrm{Rb}$, and $300 \mathrm{ppm}$ for $\mathrm{Cu}$. 
Disko Bugt. Fig. 2 shows that high $\mathrm{MgO}$ values delineate the amphibolitic parts of supracrustal sequences in the area. The high value at the east coast of Arveprinsen Ejland marks the presence of a large dolerite dyke. A considerable difference is noticed between the generally low $\mathrm{MgO}$ level $(<1.6 \%)$ in the gneiss terrain to the south, and the medium to high level $(1.5-4.0 \%)$ in the gneiss in the north-western corner of Nûgssuaq. The high level may indicate the presence of a dioritic component, or more probable the occurrence of amphibolites included in the gneiss.

The pattern for rubidium shows some distinct changes in concentration level which must be attributed to lithogeochemical changes within the established geological units. The mafic-felsic character of the volcano-sedimentary rocks is reflected in the varying Rb-values in these rocks. Further it is noted that there are three levels in the gneiss areas: a low level $(<50 \mathrm{ppm})$ in the southern gneiss terrane north and south of Jakobshavn and also in the central part of the Atâ tonalite; a medium to high level ( $50-90 \mathrm{ppm})$ in the gneiss surrounding the central Atâ tonalite as well as in the western part of the Nûgssuaq area; and finally a high level (90-120 ppm) in the eastern Nûgssuaq gneiss. Tentative boundaries are drawn between the concentration levels. It is noteworthy that the northern boundary of the southern low- $\mathrm{Rb}$ area is not coincident with the major shear zone (A-A in fig. 2) which Escher \& Pulvertaft (1976) suggested as representing the boundary between the Nagssugtoqidian and Rinkian mobile belts. The low-Rb boundary follows a set of faults with the same direction, lying c. $5 \mathrm{~km}$ north of the major zone (cf. Knudsen et al., 1988). The differentiation of the gneiss terrane by the $\mathrm{Rb}$-concentration levels adds a new dimension to the interpretation of the origin and interrelation of the various gneiss units.

The Cu map for the Disko Bugt region shows a low background level and a number of scattered medium and high values mainly, but not exclusively, confined to the supracrustal rocks. The supracrustal rocks are known to contain sulphide mineralisation with chalcopyrite (Knudsen et al., 1988), and this stream-sediment survey confirms that $\mathrm{Cu}$ is frequently associated with these rocks. The medium to high $\mathrm{Cu}$ values in northeastern Nûgssuaq coincide with medium to high $\mathrm{MgO}$ values and thereby support the assumption of the presence of basic (supracrustal?) rocks.

Godthåb. Fig. 3 shows a belt of high $\mathrm{MgO}$ values $(3.0-5.0 \%)$ with a north-north-east trend following the major mafic sequences of the Malene supracrustal rocks. The north-western corner of the Fiskefjord district is rich in $\mathrm{MgO}(2-10 \%)$ which reflects dioritic to gabbroic rocks and frequent occurrences of ultramafic bodies (Garde et al., 1987; Garde \& Marker, 1988).

In the distribution pattern for rubidium a diagonal zoning is observed with a low-level area $(<30 \mathrm{ppm})$ to the north-west, a central north-east trending zone with high $\mathrm{Rb}(50-180 \mathrm{ppm})$ and decreasing values towards the south-east. The low-Rb areas correspond largely to the distribution of granulite facies gneisses, and the high-Rb zone appears as a regional crustal feature transecting gneiss and granite units of different age and origin, i.e. Amîtsoq gneiss, Nûk gneiss and Qôrqut granite (Bridgwater et al., 1976). The high-Rb zone is bounded towards the north-west by major faults and to the south-east the boundary appears to coincide with a major thrust according to recent field work by Nutman \& Friend (1988). The high-Rb zone may thus represent a segment of high-level crust in tectonic contact with deeper levels. Data from an airborne radiometric survey support this hypothesis by showing that the Rb-rich zone is also enriched in $U$ and Th (Steenfelt, 1987a).

The fault running across Nordlandet appears to coincide with a change in concentration level for both $\mathrm{Rb}$ and $\mathrm{MgO}$ which may indicate a significant displacement along the fault. The $\mathrm{Cu}$ map shows a low and unsteady

Table 3. Districts with clusters of high values of ore forming elements

\begin{tabular}{|c|c|}
\hline Districts & Anomalous metal contents \\
\hline \multicolumn{2}{|l|}{ Disko Bugt } \\
\hline $\begin{array}{l}\text { Oqaitsut } \\
\text { Arveprinsen } \\
\text { Ejland } \\
\text { Eqe } \\
\text { Anap nunâ } \\
\text { Nugssuaq } \\
\text { south coast }\end{array}$ & $\begin{array}{l}\mathrm{MgO}, \mathrm{MnO}, \mathrm{V} \\
\mathrm{Au}, \mathrm{Cr}, \mathrm{Cu}, \mathrm{Ni}, \mathrm{Zn} \\
\mathrm{As}, \mathrm{Au}, \mathrm{Mo}, \mathrm{V}, \mathrm{Zn} \\
\mathrm{Ag}, \mathrm{As}, \mathrm{Au}, \mathrm{Ba}, \mathrm{Ni}, \mathrm{Zn} \\
\mathrm{Ag}, \mathrm{As}, \mathrm{Au}, \mathrm{Ba}, \mathrm{Cr}, \mathrm{Ni}, \mathrm{V}, \mathrm{W}, \mathrm{Zn}\end{array}$ \\
\hline \multicolumn{2}{|l|}{ Godthảb } \\
\hline $\begin{array}{l}\text { Fiskefjord } \\
\text { Bjørneø } \\
\text { Ivisârtoq }\end{array}$ & $\begin{array}{l}\mathrm{Cr}, \mathrm{Ni} \\
\mathrm{Cr}, \mathrm{Cu}, \mathrm{MnO}, \mathrm{Ni}, \mathrm{P}_{2} \mathrm{O}_{5}, \mathrm{TiO}_{2}, \mathrm{~V} \\
\mathrm{Ag}, \mathrm{Au}, \mathrm{Co}, \mathrm{Cr}, \mathrm{Cu}, \mathrm{Ni}, \mathrm{W}, \mathrm{Zn}\end{array}$ \\
\hline
\end{tabular}

The anomalies are defined as values above the 98 th percentile for both areas. The threshold values used are: Ag 5 ppm, As 80 ppm, Au 5 ppb, Ba 950 ppm, Co 80 ppm, Cr 400 ppm, Cu 170 $\mathrm{ppm}, \mathrm{MnO} 0.8 \%$, Mo $5 \mathrm{ppm}$, Ni $210 \mathrm{ppm}, \mathrm{P}_{2} \mathrm{O} 50.4 \%$, $\mathrm{TiO}_{2}$ $1.1 \%$, V 185 ppm, W 10 ppm, Zn 170 ppm.

$\mathrm{Ba}, \mathrm{Cr}, \mathrm{Cu}, \mathrm{Ni}, \mathrm{P}_{2} \mathrm{O}_{5}, \mathrm{TiO}_{2}, \mathrm{~V}, \mathrm{Zn}$ : X-ray fluorescence analysis by the Geological Survey of Greenland.

$\mathrm{Ag}, \mathrm{As}, \mathrm{Au}, \mathrm{Co}, \mathrm{Mo}, \mathrm{W}$ : Instrumental neutron activation analysis by Bondar-Clegg. 

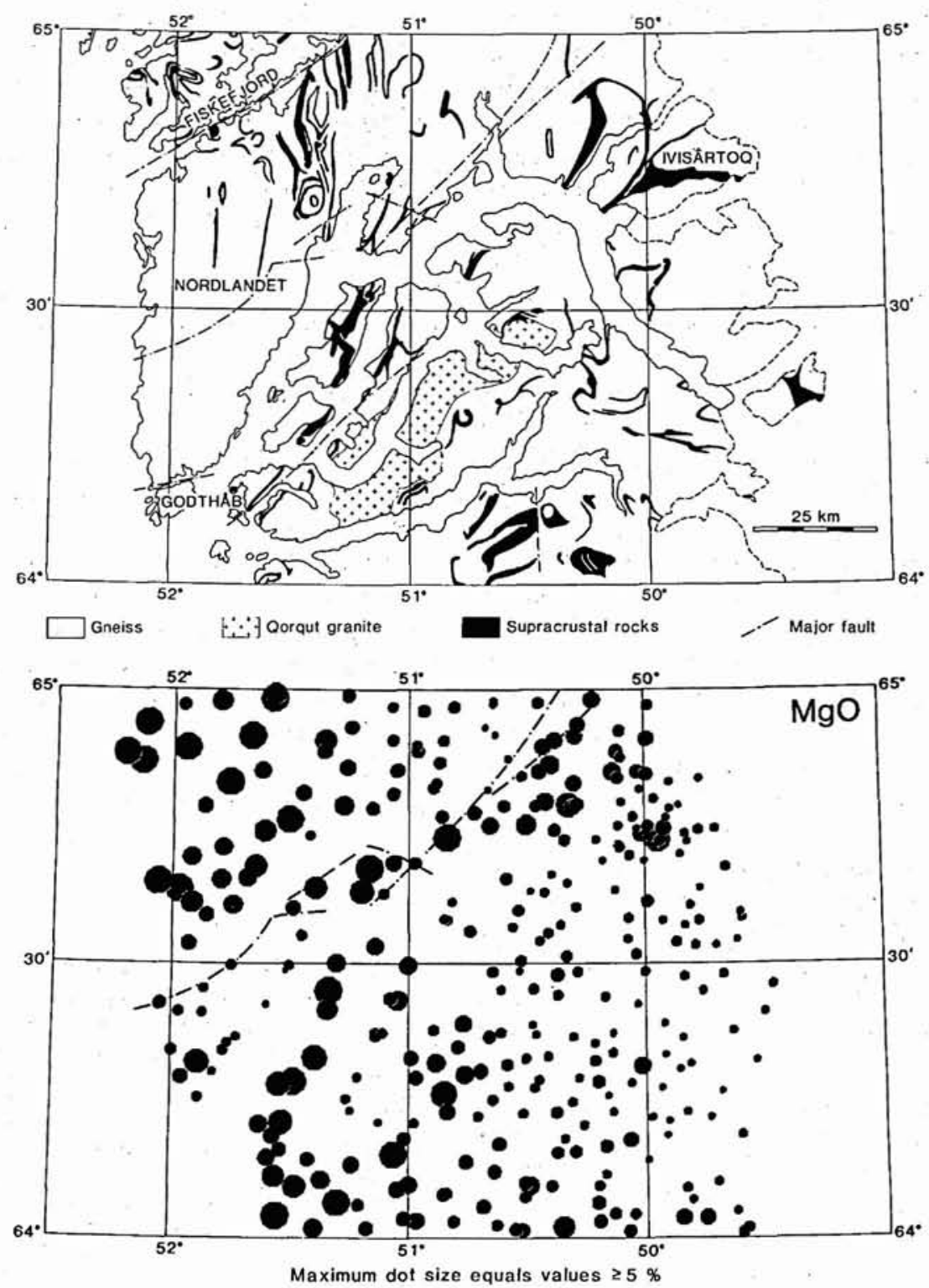

Fig. 3. Simplified geology of the Godthåb region and corresponding element distribution maps based on X-ray fluorescence of

background variation and a few high values. In general there are less high values associated with the supracrustal sequences in the Godthåb region than in the Disko Bugt region.

\section{Geochemical anomalies}

Samples with unusual chemical composition relative to the geochemical background variation and to the geology of the drainage area may be indicative of mineralisation. The data are not fully evaluated to define and interpret geochemical anomalies but a number of sites containing clusters of high values for one or more oreforming elements are listed in Table 3 together with the anomalous elements.

In the Disko Bugt region the anomalies are linked to the supracrustal rocks which appear to have a potential for base metals, and Ag and $\mathrm{Au}$. This agrees with Knud- 

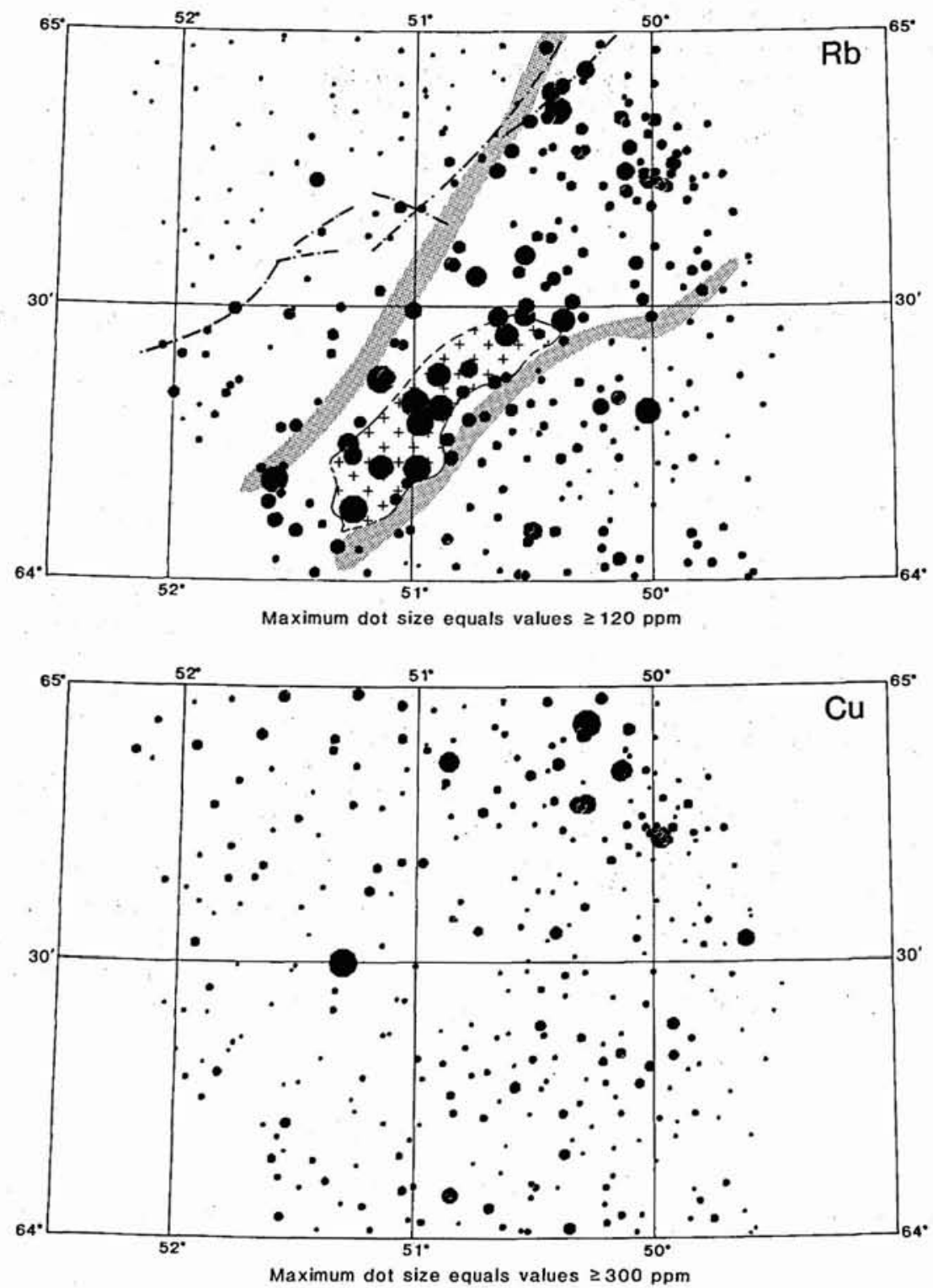

stream sediment. Symbols as in fig. 2 .

sen et al. (1988) who report the frequent occurrence of sulphide mineralisation at Eqe and on Arveprinsen Ejland (fig. 2). The results for gold are reported by Steenfelt $(1987 \mathrm{c})$. The anomalous sites will be targets for further field work in 1988.

Anomalies in the Godthåb region are scattered and comprise two types. A number of high $\mathrm{Cr}$ and $\mathrm{Ni}$ values occur in the magnesium rich north-western part of the survey area and are believed to reflect chromite bearing peridotite bodies in the gneiss. Dunite bodies were ob- served during the sampling by the author and are also described by Garde et al. (1987). A few other anomalies (Table 3 ) are associated with the supracrustal rocks at Bjørneø, and particularly at Ivisârtoq (fig. 3). The mineral potential of the supracrustal rocks of the Godthåb region is treated by Appel $(1984,1986,1988)$ based on results from analysis of panned concentrates of stream sediment and detailed geological prospecting. The distributions of gold values are reported by Steenfelt (1987c). 
Acknowledgements. The assistance in the field by Else Dam and Ulla Hjorth Jakobsen is gratefully acknowledged. The program used to generate the symbol maps was implemented by $\mathrm{T}$. Tukiainen following principles developed by N. Gustavsson, Geological Survey of Finland.

\section{References}

Appel, P. W. U. 1984: Tungsten mineralisation in the Godthåb area, West Greenland. Rapp. Grønlands geol. Unders. 120, 51-54.

Appel, P. W. U. 1986: Strata bound scheelite in the Archean Malene supracrustal belt, West Greenland. Miner. Deposita 21, 207-215.

Appel, P. W. U. 1988: Scheelite in Malene supracrustals of the Ivisârtoq area, southern West Greenland. Rapp. Grønlands geol. Unders. 140.

Bridgwater, D., Keto, L., McGregor, V. R., \& Myers, J. S. 1976: Archaean gneiss complex of Greenland. In Escher, A. \& Watt, W. S. (edit.) Geology of Greenland, 18-75. Copenhagen: Geol. Surv. Greenland.

Escher, A. \& Pulvertaft. T. C. R. 1976: Rinkian mobile belt of West Greenland. In Escher, A. \& Watt, W. S. (edit.) Geology of Greenland, 104-119. Copenhagen: Geol. Surv. Greenland.

Garde, A. A. \& Marker, M. 1988: Corundum crystals with blue-red colour zoning near Kangerdluarssuk, Sukkertoppen district, West Greenland. Rapp. Grønlands geol. Unders. 140.

Garde, A. A., Jensen, S. B. \& Marker, M. 1987: Field work in 1986 in the Fiskefjord area, southern West Greenland. Rapp. Grønlands geol. Unders. 135, 36-42.
Kalsbeek, F. 1986: The tectonic framework of the Precambrian shield of Greenland. A review of new isotopic evidence. Rapp. Grønlands geol. Unders. 128, 55-64.

Kalsbeek, F., Taylor, P. N. \& Pidgeon, R. T. in press: Unreworked Archaean basement and Proterozoic supracrustal rocks from northeastern Disko Bugt, West Greenland: implications for the nature of Proterozoic mobile belts in Greenland. Can. J. Earth. Sci.

Knudsen, C., Appel, P. W. U., Hageskov, B. \& Skjernaa, L. 1988: Geological reconnaissance in the Precambrian basement of the Atâ area, central West Greenland. Rapp. Grønlands geol. Unders. 140.

Nutman, A. P. \& Friend, R. L. 1988: Evolution and assembly of Archaean terranes in the Kapisigdlit area, southern West Greenland. Rapp. Grønlands geol. Unders. 140.

Petersen, T. S. \& Sørensen, I. 1980: XRF 2: A Fortran programme for treatment of XRF data obtained with an absolutely calibrated XRF-spectrometer. Geol. Surv. Denmark, Yb. 1979, 125-138.

Steenfelt, A. 1987a: Geochemical mapping and prospecting in Greenland - a review of results and experience. J. geochem. Explor. 29, 183-205.

Steenfelt, A. 1987b: Geochemical trends in central and western North Greenland. Rapp. Grønlands geol. Unders. 133, 123-132.

Steenfelt, A. 1987c: Gold in the fine fraction of stream sediments from supracrustal sequences in West Greenland. Intern. GGU rep., 10 pp.

Steenfelt, A. \& Kunzendorf. H. 1979: Geochemical methods in uranium exploration in northern East Greenland. In Watterson, J. R. \& Theobald, P. K. (edit.) Geochemical exploration 1978, 429-442. Rexdale, Ontario: Association Exploration Geochemists.

\title{
Stream sediment sampling in the Atâ area, central West Greenland
}

\author{
Peter W. Uitterdijk Appel and Christian Knudsen
}

In 1982 scheelite was identified in stream sediments in the Nuuk/Godthåb area, about $600 \mathrm{~km}$ south of Atâ. Subsequently a regional stream-sediment programme was carried out in the Nuuk area from 1982 to 1987 as a result of which scheelite was found to be quite abundant in the $3800 \mathrm{~m} . \mathrm{y}$. old Isukasia supracrustal rocks as well as in the 3300 to $3000 \mathrm{~m} . \mathrm{y}$. old Malene supracrustal sequence (Appel, 1988). It.was also recognised that there is a close correlation between the number of scheelite grains and the gold content of the heavy mineral concentrates in the Nuuk area (Appel, 1988).
In the Atâ area (fig. 1) extensive outcrops of supracrustal rocks are found. In these supracrustals, which have been metamorphosed to greenschist and amphibolite facies, abundant sulphide-rich horizons are found, as well as sulphide-bearing breccia zones with appreciable gold contents (Knudsen et al., 1988).

During the 1987 field season geological reconnaissance mapping was carried out in two of the supracrustal areas and the gneiss-granite complex enclosing the supracrustal rocks -was investigated (Knudsen et al., 1988). A limited programme of stream-sediment sam- 